\title{
PATENTS AND THE NEW TRUST PROBLEM
}

\author{
JOSEPH BORRIN*
}

Virtually every product, process and enterprise characteristic of our present economy is in some way affected by a patent or a combination of patents. Not simply machirres, but also food, clothing, medicines, energy itself, are made subject to the patent rights of individuals or corporations. Few phases of modern life have escaped the effects of patents.

A patent in itself is simply governmental recognition that an inventor has created a device, process or method of production which is novel and usable. The phrase "conception, novelty and workability" is a technical rubric summarizing the legal test of whether a patent claim is valid. In the United States this process of governmental recognition is based on a provision in the Constitution (Article $\mathrm{x}$, Section 8, Clause 8) reading as follows:

The Congress shall have the power ... to promote the progress of science and useful arts by securing for limited times to authors and inventors the exclusive right to their respective writings and discoveries.

When the clause referring to patents was inserted in the Constitution, the handicraft technique of industry was characteristic of the economy and individual patents commonly stood alone without relationship to other patents or processes. It is interesting to note that during this period the Supreme Court of the United States in one of its earliest patent decisions observed as to the basic purpose of this clause: ${ }^{1}$

While one great object [of the patent law] was, by holding out a reasonable reward to inventors and giving them an exclusive right to their inventions for a limited period, to stimulate the efforts of genius, the main object was "to promote the progress of science and useful arts."...

With the advent of machine technique, the individual patent was found very often inoperative except when exercised in conjunction with another patent or collation of patents. The courts, however, have held that even though the workability of a patent may depend upon its conjunction with others, it still retains all its individual character of separate property. As a result, deadlocks have become a common characteristic of the patent system. To what extent patents have been utilized to

B.S., 1933, M.A., I935, New York University. Economist in charge of Patent Unit, Antitrust Division, U. S. Department of Justice. Formerly Director of Research, Committee on Patents, U. S. House of Representatives. Co-author of Television: A Struggle for Power (I938).

${ }^{1}$ Pennock v. Dialogue, 2 Pet. I, I9 (U. S. 1928), per Story, J. 
block the progress of industries and to make predatory attacks in the courts upon individual inventors and entrepreneurs; what effect this has had upon the ability of individuals and corporations to exercise restrictive powers to restrain trade, block technological advance, secure monopolies, are questions which have been examined by the Temporary National Economic Committee in its hearings last winter. ${ }^{2}$

Before identifying the abuses in detail, it is necessary to give a brief synopsis of the United States Patent Laws. It is most important to realize that Congress may revise or repeal these laws or even neglect to establish any at all under the powers granted it by the Constitution. There is nothing mandatory upon Congress in the constitutional provision to authorize the granting of any patents.

The first patent law was passed in I790. Not at all complex, it provided that "any useful art, manufacture, invention, or device, or any improvement therein not before known or used" might be patented. The right of exclusive ownership was to last for fourteen years. Administration was delegated to the Secretary of State, an office at that time held by Thomas Jefferson. A patent board, consisting of the Secretary of State, the Secretary of War, and the Attorney General, was authorized to settle disputes. Jefferson, himself an inventor, is reputed to have had misgivings about the issuance of patent monopolies, but also felt "that ingenuity should receive liberal encouragements." The first patents issued were relatively simple in nature and the total number comparatively small. But with the steady growth of manufactures, applications for patents became sufficiently numerous so that Congress found it advisable to pass the Patent Act of 1836 . This law provided for a Patent Office as a separate bureau to undertake a systematic examination of inventions and to give concrete content to the patent requirements of conception, novelty and workability. The term of the patent was extended from fourteen to seventeen years in 1869. In 1870 all the previous acts were combined and revised to form the basic framework for our present patent system.

Without attempting any detailed analysis of the evolution of the legislation, it may be stated, in agreement with the views of most experts, that from the first patent law to date, changes, additions, and revisions of the law have been largely procedural, neglecting fundamental change.

By judicial interpretation a patent right has come to include the power (I) to withhold the invention from use by anybody; (2) to use it exclusively; (3) to sell or assign with all rights; (4) to license its use or sale; (5) to sue infringers. This was pungently stated by the Supreme Court in the case ${ }^{3}$ involving the original Bell telephone patents:

Counsel seemed to argue that one who has màde an invention and thereupon applies for a patent therefor, occupies, as it were, the position of a quasi trustee for the public; that he is under a sort of moral obligation to see that the public acquires the right to the free use of that invention as soon as it is conveniently possible. We dissent entirely from the

\footnotetext{
${ }^{2}$ Hearings Before the TNEC, 75th Cong., 3d. Sess. (1938) Pts, 2, 5; TNEC, Preimatnary Report Pursuant to Pub. Res. No. I13, Sen. Doc. No. 95, 76th Cong., ist Sess. (1939).

${ }^{2}$ U. S. v. American Bell Telephone Co., I67 U: S. 224, 250 (I897).
} 
thought thus urged. The inventor is the one who has discovered something of value. It is his absolute property. He may withhold the knowledge from the public, and he may insist upon all the advantages and benefits which the statute promises him who discloses to the public his invention.

The development of steam and electric power, chemical processes, and a myriad of integrated manufacturing systems, has led to a lag between law and technology which obviously is far beyond the comprehension of the original framers of the patent system, yet in the case quoted above we have a legally primitive interpretation of patent rights. The decision has served as a ruling case in spite of an increasingly complex relationship between private and public rights. Where originally single patents often covered complete processes, and even entire industries, they have now come to relate to only parts of larger, more involved techniques already substantially mechanized. Consequently, patents have become dependent upon each other, and unless all the necessary patents for a specific operation are owned or controlled or licenses are acquired, manufacturing in many lines of industry becomes legally hazardous. An example of this is given in the following quotation:4

We went into our factory and if we tried to wind the coil this way somebody out in Oklahoma had a patent for it. If we tried to wind it another way somebody else in Peoria, Illinois had a patent for it; and if we decided not to wind it at all we found omitting it was covered by a patent of somebody else. 4

A further consequence was the tremendous growth in the number of patents, so that it is now estimated the Patent Office of the United States has issued over 2,000,-. ooo patents, of which over 740,000 are active at the present time. The mere mechanics of indexing and classifying is a Herculean task which has never been 2dequately carried out.

With the diversified ownership of patents in industries, conflict has necessarily followed, and as a result the Patent Office and the federal courts are handling an ever increasing number of interference actions and patent infringement suits. Patent litigation is an extremely complex procedure involving large expense and long periods of time. It is estimated by various experts and patent lawyers that to carry a single patent suit through the Supreme Court of the United States costs between seventy-five thousand and a million dollars, depending upon the financial reserves of the litigants, the character of the patents, and the ability of the attorneys to delay the proceedings and harass each other. An examination of the procedure of such litigation will make this clear. The litigant must be ready to bear the following typical costs: search in the United States Patent Office, foreign patent offices, publications, gazettes, etc., the fees for testimony by expert witnesses, attorneys' fees, the recording of testimony, the printing. of records, and very often other special costs deliberately introduced to coerce a relatively poor opponent. He must be ready to repeat these costs originally assumed at the Patent Office when he appears in the

\footnotetext{
"Hearings before the House Committee on Patents on H. R. 4523, 74th Cong., Ist Sess. (1935) 563. 564.
} 
United States District Court, again in the Circuit Court of Appeals, and finally in the Supreme Court. ${ }^{5}$ Further, he must be able to stand the test and cost of time, for the complexity of patent litigation has made it an extremely slow proceeding.

As a result, certain industries, especially those most afflicted by patent deadlocks, attempt to circumvent the difficulties of conflict by private contracts. In some cases, notably aviation and radio, where the national defense was involved, the Government has taken part in attempting to eliminate the confusion inherent in the patent problem. The basic idea in each instance was to achieve some sort of a patent consolidation as a means of eliminating or forefending a deadlock.

Roughly speaking, three forms of organization have emerged from time to time in an effort to circumvent the patent impasse: (I) single ownership of all patents by an individual or corporation; (2) patent pooling associations; (3) cross-licensing agreements. It is in the operation of these patent combinations, the avowed purpose of which was to break patent deadlocks, that abuses have developed.

With the organization of these patent combinations, there has been created a corresponding aggregate of concentrated financial power. By virtue of the exclusive rights granted under the patent law these combinations have used the assembled patents as a convenient device to restrain competition and the free flow of commerce. The two main methods whereby this device is employed are (I) the patent infringement suit, and (2) the license agreement.

As was pointed out earlier, patent infringement suits are extremely costly. Consequently, the party in such litigation with larger resources than his opponent's finds the disparity a decided if not decisive advantage. It is not necessary to describe here how this situation becomes magnified when there is a concert of interest such as exists in the various forms of patent combinations. Litigation in the patent field is no longer confined to use as an instrument of adjudicating questions of legitimate dispute in the courts. Rather it has become an importane instrument of business aggression and competition. By threatening less powerful individuals with infringement suits or by similar intimidation of the latter's customers, holders of groups of patents have reduced competition in many fields of industry to a vestigial state. With the ability to back up their threats by aggressive infringement suits, they have been able to perpetuate their monopoly long after the expiration of the basic patents. By patenting improvements of no real consequence and by obtaining patents of questionable validity, they have built up formidable weapons. The fact that many of the patent privileges asserted may rest upon spurious grounds is beside the point, since the expense of establishing that fact in the courts is usually insupportable by those against whom these weapons are employed. The independent as a rule finds it beyond his means either to institute or defend such litigation. He must either accept a license for use of the patents owned by the controlling group or endeavor to continue competition under a severe handicap. In addition, monopolies have been perpetuated after the expiration of patents because of original preemption of the field.

\footnotetext{
' Cases involving the same patent may be instituted in a number of district courts and carried on appeal to various circuit courts of appeals.
} 
But hardly a less effective instrument of limiting competition and maintaining control is the license agreement. By means of this device the holder of a group of patents, whether a single corporation or an association, may impose limitations upon the licensees which seriously affect the latters' ability to compete. Quota systems of manufacture and sale are established as well as provisions for maintaining prices. Not infrequently the licensee is forced to agree to purchase raw material, repair and replacement parts, or even to purchase service from the licensor, none of which may be covered by patents. In addition, he may be forced to pay royalties on unpatented articles and operations. If he does not comply, he is always subject to a cancellation of the license or to the risk of a patent infringement suit. The fact that some of the restrictions imposed may be of doubtful legality or even clearly invalid under decisions of the Supreme Court does not destroy the licensor's de facto power to impose them.

A further abuse of the license agreement exists in the relation between large corporations operating in closely related fields. Using the assembled patents as the focal point of legality, they have divided several fields in such a manner that each receives exclusive rights-in a particular area with a guaranty of no competition from the others. By trading patent rights and acting in concert against all would-be interlopers, they effect mutually protected monopolies.

The formidable arrays of patents collected by industrial combinations for the purpose of dividing fields into non-competitive spheres, establishing quota systems of manufacture, controlling the price and use of non-patented articles and services, "blocking off" developments and "fencing in" licensees" and competitors, can scarcely be considered an incentive to genius or a promotion of "science and useful arts." Instead patents have to some extent become instruments of oppression, representing economic waste through the non-utilization or restricted utilization of the resources of knowledge they embody, rather than eliminating waste by spurring increased efficiency.

Until very recently no systematic attack has been made on the problems presented by the abuse of patent privileges. Within the past year, however, this problem has become the object of two major inquiries.

The first of these has been conducted by the Antitrust Division as part of the program of the Temporary National Economic Committee. In President Roosevelt's message to the Congress of April 20, 1938, which led to the creation of the TNEC, he listed among the items to be embraced in the study he proposed, "Amendment of the patent laws to prevent their use to suppress inventions, and to create industrial monopolies." The joint resolution creating the TNEC directed the Committee to study and investigate "the effect of existing tax, patent, and other Government policies upon competition, price levels, unemployment, profits, and consumption."7 Accordingly, one of the first subjects of inquiry before the TNEC was the patent problem. The Antitrust Division's part in this study was directed principally to a

'SEN. Doc. No. I73, 75th Cong. 3d Sess. (1938).

${ }^{7}$ Pub. Res. No. II3, 75th Cong., 3d Sess. (1938) \$2(a)(3). 
depiction of the contrasting uses of patents in the automobile, glass container, and beryllium industries.

The first of these industries has been conspicuous for its lack of patent litigation and the methods which it has used to make patents in the field accessible to all responsible producers. In the second industry, two companies owned the principal patents on glass container machinery. "Through this control," to quote the TNEC Preliminary Report, "production has been adjusted and allocated, and prices stabilized indirectly, at least, through the maintenance of the production rate. . . . The patent monopoly was further employed through the refusal to grant licenses, to prevent new enterprises from starting new glass container plants.... Large interests in the industry often resorted to litigation to protect their patents with the result that some of the producers were eliminated." 8 The beryllium industry was selected as representative of an infant industry since the industrial use of beryllium is of rather recent origin. The hearings "showed how attempts at control, limitation of competition, and even cartelization were being made at the very early stages of this industrial development."

Prior to the submission of its Preliminary Report, the TNEC requested the Department of Justice to submit recommendations for legislation calculated to eliminate the abuses of the patent privilege. The Department of Justice suggested: $:^{10}$

I. It should be made unlawful for any person to sell or assign a patent, or to grant any right or license under a patent, on any condition which restricts the assignee or grantee in respect of the amount of any article which he may produce under the patent, the price at which he may sell any such article, the purpose for which or manner in which he may use the patent or any article produced thereunder, or the geographical area within which he may produce or sell such article. The foregoing prohibitions should be supplemented by a further prohibition against any other restriction embodied in a condition to any such assignment or license, which would tend substantially to lessen competition or to create a monopoly, unless such restriction is necessary to promote the progress of science and useful arts. These prohibitions, however, should not apply to any assignment of a patent or any grant of a license under a patent for use exclusively outside the United States and its territories and possessions.

In short, the owner of a patent would enjoy the full patent monopoly if he elected to retain the exclusive privilege of producing or selling under the patent himself. He would be free to assign the patent; to grant an exclusive license; and to grant licenses to anyone he pleased. But, if he grants a license, the license must be general and unrestricted, unless he is prepared to demonstrate that a particular restriction (other than restrictions in respect of price, production, use, or geographical area) is necessary to promote science and useful arts. Restrictions in respect of price, production, use, or geographical areas would be unconditionally outlawed.

2. It should be made unlawful for any person to whom a patent has been issued or who has in any other way acquired any patent or any interest in or right or license under a patent, to sell, lease, or otherwise dispose of any article produced or sold under such patent or any such right or license on any restrictive condition of the kind described in paragraph $\mathrm{x}$.

3. It should be made mandatory for any sale, assignment, or other disposition of any patent or of any interest in or right or license under a patent to be evidenced by an instru-

- Preliminary Report, supta note 2 , at 7-8. $\quad{ }^{8}$ Id. at 8.

${ }^{10} \mathrm{Id}$. at $16-18$. 
ment in writing. Similarly, any condition, agreement, or understanding relating to any sale or other disposition of any article produced or sold under a patent by a person to whom such patent has been issued or who has in any other way acquired such patent or any interest in or right or license thereunder, should be required to be evidenced by an instrument in writing. The seller or assignor in such case would be required to file a copy of such written instrument with the Federal Trade Commission within 30 days after execution. A register of these copies should be kept by the Federal Trade Commission, and both the register and the copies should be held available for inspection by the Attorney General, the Commissioner of Patents, or any officer designated by either.

4. No action based upon a charge of infringement of any patent, whether for damages, for an injunction, or for any other relief, should be permitted against any licensee under a patent or against any purchaser or lessee of any article unless either (a) the plaintiff has previously prosecuted to successful judgment an action against the grantor of the license or the seller or lessor of the article, as the case may be, for infringement arising out of or in connection with the granting of such license or the sale or lease of such article; or (b) jurisdiction over the grantor, seller, or lessor cannot be obtained in any court of the United States.

A provision to the foregoing effect would help meet one of the most serious abuses in the patent field: The use of litigation as a deliberate weapon of business aggression, rather than as an instrument for adjudicating honest disputes.

5. If any person who owns a patent or an interest in or exclusive right under a patent, violates any of the prohibitions described in paragraphs $I$ and 2 above, he should forfeit his patent or his interest in or right under a patent to the United States, and such forfeiture should be recoverable in a civil action against such person by the United States. It should be provided that, upon a proper showing in such an action, a judgment should be entered requiring the deffendant to assign his patent, or interest in, or right under a patent, to the United States, such assignment to be received by the Secretary of the Treasury in the namie of the United States. Thereafter, the patent or patent right would be offered for sale under the direction of the Secretary of the Treasury in the manner prescribed by law.

A provision to the foregoing effect would adapt to the patent situation a familiar principle of law: That the abuse of a privilege granted by the State-e. g., public-utility franchises, licenses to sell securities, etc.-should result in forfeiture of that privilege. In this case, it seems wise to provide that the patent should be seized and resold, and so kept alive for useful exploitation, rather than to provide for its cancelation.

6. It should be made clear that the provisions described in paragraphs $I$ to 5 shall be applicable to any extension, renewal, or modification of any existing license, contract of assignment, or contract of sale or other disposition, with the same force and effect as to any new license, sale, assignment, or other disposition.

The submission of these recommendations did not constitute an admission that the conduct for which statutory prohibitions were sought was entirely legal under the existing law. The antitrust decisions relating to the restraints imposed through the patent device would not sustain such a position. It is the inadequacy of decisions which concerns the Department. This is made clear by the following statement from the Department of Justice's press release on its patent program:11

$\mathrm{U}_{\mathrm{p}}$ to the present time, all of the practices used to control and dominate industry by patents have not been presented for judicial determination. The cases that have arisen have involved isolated situations with the result that the decisions have been insufficient

\footnotetext{
${ }^{11}$ Dep't of Justice, Public Statement, Dec. II, I939, p. 5.
} 
guides either to the Government or to business men. The Department wishes to have a judicial determination of the validity of all the patent practices now prevalent throughout industry which it believes unlawful under the antitrust laws. The Department believes that these practices are economically unsound and that a full presentation of the economic and social consequences of these practices will bring about judicial clarification of most of the apparent conflicts between the scope of the patent grant and the antitrust laws.

Thus it is hoped that there will be clarification of the line at which legal usage of patent rights ends and illegal restraints and combinations in trade begin.

It was with a view to revealing further the facts relating to the use of patents to control competition and to obtain judicial determinations of the validiy of patent practices believed to be economically unsound that the Antitrust Division undertook the second attack on the patent problem. This was by means of a grand jury investigation. A grand jury will shortly be convened in New York City to investigate "the extension to which patent rights are improperly utilized to control various industries and to prevent the free play of competitive forces in the market." 12 This inquiry is to "involve a number of different industries and every type of practice which the Department questions."13

Contemporaneously with the announcement of the New York grand jury investigation, an equity suit was commenced in the District Court of the United States for the Northern District of Ohio against twelve corporations and I03 individuals engaged in the business of producing glassware machinery and glass containers. This proceeding took the form of a civil suit for an injunction because the facts in the case were made public at the TNEC hearings at which a number of the individual defendants testified.

In the public statement issued at the time of the commencement of this suit the results which are anticipated from it were stated as follows: $:^{14}$

This suit is therefore brought to break a bottle-neck in order to allow to business men equal opportunity to enter the glassware industry. As old as the common law is the right of an individual to the unmolested pursuit of any calling. If persons are to be employed and capital is to be turned into account, individuals must be free to embrace any industrial opportunity. Certainly this should apply to the glassware industry as well as to any other industry in the United States. If the facts charged in this case are established as a violation of the antitrust laws, it is expected that there will be a restoration of competition in the glass machinery and glass container business. This field will then be opened for the employment of additional capital and labor; prices and production will be established on a competitive basis; the stimulating effects of competition should be felt in the field of research and technological advance; and through unrestricted output and reasonable price a necessity of modern life will be brought within closer reach of multitudes of people and will find a more secure place in the American standard of life.

With the successful completion of that part of the program of the Department of Justice which deals with patent litigation, it seems probable that the line of demarcation between the proper and improper, use of the patent privilege under the Sherman Act will be clearly ascertainable for the first time in the history of that measure.

\footnotetext{
21 Id. at p. 2.

${ }^{12}$ Id. at p. 5 .

${ }^{26}$ Id. at p. II.
} 